\title{
PREFERENCE BIAS AND OUTSOURCING TO MARKET: A STEADY-STATE ANALYSIS
}

\author{
RAYMOND RIEZMAN \\ PING WANG
}

\section{CESIFO WORKING PAPER NO. 2222 \\ CATEGORY 7: TRAde Policy \\ FEBRUARY 2008}

Presented at CESifo Area Conference on Global ECONOMy, JANUARy 2008

\footnotetext{
An electronic version of the paper may be downloaded

- from the SSRN website: www.SSRN.com

- from the RePEc website: - from the CESifo website: 


\title{
PREFERENCE BIAS AND OUTSOURCING TO MARKET: A STEADY-STATE ANALYSIS
}

\begin{abstract}
We analyze a model that focuses on the export/outsource decision. Outsourcing has the advantage of providing better information about local preferences. The disadvantage is that producing in the host country also means using the inferior technology embodied in the local capital. The decision of whether to offer an outsourcing contract weighs these two effects against each other. The host country accepts the outsourcing contract if the higher price they pay for the outsourced good is worth the benefit of consuming a manufactured good closer to their ideal variety. These results suggest that as low income countries develop they become a more attractive destination for outsourcing because the quality of their capital improves and the local market is more lucrative. In addition, the developing low income country finds the outsourcing contract more attractive since their increased demand for the correct variety of the manufactured good increases. This suggests that preference based outsourcing is more likely to occur with higher income host countries.
\end{abstract}

JEL Code: F20, F21, F23.

Keywords: outsourcing, multinational firms, foreign direct investment.

\author{
Raymond Riezman \\ Department of Economics \\ University of Iowa \\ Iowa City, IA 52242 \\ USA \\ raymond-riezman@uiowa.edu
}

\author{
Ping Wang \\ Department of Economics \\ Washington University in St. Louis \\ Campus Box 1208 \\ USA - St. Louis, Missouri 63130 \\ pingwang@artsci.wustl.edu
}

December 2007

We would like to dedicate this paper to the memory of our dear friend and colleague Koji Shimomura whose stimulating work in trade and growth has inspired all of us. We are grateful for comments and suggestions by Eric Bond, Ronald Jones, and participants of the Midwest International Trade Meeting and the Kobe Conference in memory of Koji Shimomura. 


\section{Introduction}

The study of the causes and consequences of outsourcing of production by firms has received increasing attention since the turn of the century (e.g., Jones, 2000, Grossman and Helpman, 2002 and 2004, and Antras 2004). This literature focuses primarily on the outsourcing decision based on the theory of the firm, regarding the make-or-buy outcome as an equilibrium phenomenon. Our paper develops a preference-based theory of outsourcing in which outsourcing is beneficial because it mitigates the information problem with respect to the identification of local tastes for the manufactured good - that is, the local economy is engaged in "design for manufacturing" to suit local preferences.

We consider a simple, dynamic framework with the following specific features.

- There are two countries, a low-income developing local country and a high-income developed source country.

- There are two types of goods, a homogeneous good (food, for example) produced only in the local country and a particular variety of a manufactured good (laptop computer, for example) that may be produced in the source or the local country.

- Only the source country does R\&D to improve the production technology of the manufactured good.

- The source country may outsource production of the manufactured good to the local economy.

- Only through outsourcing can the source country firm correctly identify the local economy's variety-specific preferences.

- Each country employs a specific factor. The source country utilizes general capital for production and technology advancement, whereas the local country uses physical capital for production only.

- The manufacturers in the source country maximize its value by choosing (i) whether to outsource the production of their good and (ii) the allocation of capital between production and research.

- In the local country, an integrated representative consumer-producer decides (i) whether to accept the outsourcer's contract (if offered) and (ii) how to allocate consumption and capital 
intertemporally (and intersectorally if an outsourcing contract is offered and accepted).

We assume initially the source country exports the manufactured good to the local country, referred to as the export regime. We then identify under what circumstances the equilibrium switches from the status quo to the outsourcing regime. We show that with a sufficiently high initial capital stock, the preference of residents in the local country for the manufactured good grows over time to a level that is sufficiently high to shift preferences away from the necessity toward the manufactured good. Such shifts enhance the importance of variety-specific preferences. As a result, the local country agents find the better matched, outsourced manufactured good more desirable and are more willing to pay for it. The larger price markup over the non-ideal product makes outsourcing more profitable. Thus, our model features "cross-country complementarity" that triggers the outsourcing equilibrium when local country income is sufficiently high.

It is possible that outsourcing may never arise. In particular, this can happen if local country income is sufficiently low, capital is scarce, the discount rate high, and its consumers spend a major portion of their income on the necessity. In this case, consumers there care less about the variety of the manufactured good and hence have lower demand. This lower demand drives down the price mark up for outsourced goods thereby giving the source country less incentive to outsource. Hence, for very low income countries the export regime be the steady state.

\section{The Basic Model}

We begin with a very simple model. There are two countries (local and source), two production inputs (general capital and land), and two goods $N$ (necessity) and $M$ (manufactured good.) There are $J$ varieties $j \in\{1,2, \ldots, J\}, J>2$ of the manufactured good. Denote the $j^{\text {th }}$ variety as $M^{j}$. General capital can be thought of as a composite stock of human, physical and knowledge capital. The necessity is produced in the local country using both local capital and land. However, the manufactured good requires the input of the source country's research capital. Hence, by assumption the manufactured good can only be produced in the local country if it is outsourced. ${ }^{1}$ We focus on two sets of decisions. In the source country, the manufacturer decides (i) whether to export good $M^{j}$ or whether to outsource the production of good $M^{j}$ and (ii) how to allocate capital to production and research. In the local country, an integrated representative consumer-

\footnotetext{
${ }^{1}$ We are ruling out the possibility that the local manufacturer can purchase the research capital from the source country. For a paper that looks at this issue see Spulber (2007).
} 
producer decides (i) whether to accept the outsourcing contract (if offered) and (ii) how to allocate consumption and capital intertemporally (and intersectorally if an outsourcing contract is offered and accepted).

\subsection{Source Country}

The source country owns the "high quality" general capital that can be used for either manufacturing or research. Though the allocation of this capital is essential, its accumulation is not the focus of this paper but rather the accumulation of knowledge for production technology is the key. Thus, denoting this capital stock at the beginning of time $t$ as $H_{t}$, we assume for simplicity that there is no depreciation or accumulation.

The aggregate general capital stock at the beginning of time $t$ is divided into manufacturing capital $\left(H_{t}^{M}\right)$ and research capital $\left(H_{t}^{R}\right)$ :

$$
H_{t}=H_{t}^{M}+H_{t}^{R}
$$

and the stock of capital remains constant over time:

$$
H_{t}=H_{0}=1 \forall t=1,2, \ldots
$$

It is convenient to denote $s_{t}=\frac{H_{t}^{R}}{H_{t}}$ as the share of research capital, which under (2) also represents the stock of research-use capital.

In addition to research capital we assume that source country firms can invest in R\&D directly. The timing of decisions is as follows. At the beginning of period $t$, the existing capital stock $H_{t}=1$ is is divided into research uses $\left(s_{t}\right)$ and manufacturing uses $\left(1-s_{t}\right)$. Next, production of the manufactured good occurs based on the current technology $\left(A_{t}^{j}\right)$. Then the $\mathrm{R} \& \mathrm{D}$ investment $\left(z_{t}\right)$ is implemented, which is added to the research-use capital $\left(s_{t}\right)$ to determine next periods production technology $\left(A_{t+1}^{j}\right)$. This structure allows us to reduce the dimensionality of the state variables to one $\left(A_{t}^{j}\right.$ only).

By assuming for simplicity that the $\mathrm{R} \& \mathrm{D}$ investment and the research-use capital are perfect substitutes, the evolution of manufacturing technology is then governed by:

$$
A_{t+1}^{j}=\psi\left(A_{t}^{j}\right)^{\mu}\left(H_{t}^{R}+z_{t}\right)^{1-\mu}=\psi\left(A_{t}^{j}\right)^{\mu}\left(s_{t}+z_{t}\right)^{1-\mu}
$$

where $\psi>0$ is a technology advancement scaling factor and $\mu \in(0,1)$. 


\subsubsection{Exporting the Manufactured good}

Now consider the case in which the source country exports. We assume that the source country does not know the ideal variety of the manufactured good desired by the local country (call this variety $i$ ). So, we assume the exporter chooses some variety $j \neq i$. Manufacturing capital enters the production of $M_{t}^{j}$ immediately, but research capital only enhances future production of $M_{t+1}^{j}$.

Assume that the technologies of producing any varieties require identical resources, i.e., there are only horizontal differentiation among different varieties. The production of a manufacturing product of variety $j$ is therefore given by,

$$
M_{t}^{j}=A_{t}^{j}\left(H_{t}^{M}\right)^{\gamma}=A_{t}^{j}\left(1-s_{t}\right)^{\gamma}
$$

where $\gamma \in(0,1)$.

Given a constant discount rate $r$, the Bellman equation facing the representative firm in the source country producing and exporting the manufactured good to the local country (denoted by superscript $E X)$ can therefore be specified as:

$$
\begin{gathered}
W^{E X}\left(A_{t}^{j}\right)=\max _{s_{t}, z_{t}}\left[p_{t}^{j} A_{t}^{j}\left(1-s_{t}\right)^{\gamma}-q_{t} z_{t}\right]+\frac{1}{1+r} W^{E X}\left(A_{t+1}^{j}\right) \\
\text { s.t. } \quad A_{t+1}^{j}=\psi\left(A_{t}^{j}\right)^{\mu}\left(s_{t}+z_{t}\right)^{1-\mu}
\end{gathered}
$$

That is, the source firm's value is equal to its current profit (revenue from producing and exporting the manufactured good, net of the R\&D investment cost) plus its discounted future value.

The first-order conditions with respect to $s_{t}$ and $z_{t}$ are:

$$
\begin{aligned}
& \frac{1}{1+r} \frac{\partial W^{E X}\left(A_{t+1}^{j}\right)}{\partial A_{t+1}^{j}}(1-\mu) \psi\left(A_{t}^{j}\right)^{\mu}\left(s_{t}+z_{t}\right)^{-\mu}=\gamma p_{t}^{j} A_{t}^{j}\left(1-s_{t}\right)^{\gamma-1} \\
& \frac{1}{1+r} \frac{\partial W^{E X}\left(A_{t+1}^{j}\right)}{\partial A_{t+1}^{j}}(1-\mu) \psi\left(A_{t}^{j}\right)^{\mu}\left(s_{t}+z_{t}\right)^{-\mu}=q_{t}
\end{aligned}
$$

which equate the marginal benefit of each of the two choice variables with the marginal cost. The Benveniste-Scheinkman condition that governs the optimal path of $A_{t}^{j}$ is:

$$
\frac{\partial W^{E X}\left(A_{t}^{j}\right)}{\partial A_{t}^{j}}=p_{t}^{j}\left(1-s_{t}\right)^{\gamma}+\frac{1}{1+r} \frac{\partial W^{E X}\left(A_{t+1}^{j}\right)}{\partial A_{t+1}^{j}} \mu \psi\left(A_{t}^{j}\right)^{\mu-1}\left(s_{t}+z_{t}\right)^{1-\mu}
$$

\subsubsection{Outsourcing}

With production outsourcing, the source country still maintains full control of the technology. Since it does not produce the manufactured good it uses all of the general capital $H_{t}$ for research 
purposes. The local country's subcontracting firm determines the employment of the local capital $K_{t}^{M}$ to manufacture the contracted good. The advantage of outsourcing is that involvement of the local country enables an exact identification of the local ideal variety $i$.

It is necessary to modify the production of a manufacturing product of the ideal variety $i$ and the evolution of manufacturing technology $A_{t}^{i}$ as follows:

$$
\begin{gathered}
M_{t}^{i}=A_{t}^{i}\left(K_{t}^{M}\right)^{\gamma} \\
A_{t+1}^{i}=\psi\left(A_{t}^{i}\right)^{\mu}\left(H_{t}+z_{t}\right)^{1-\mu}=\psi\left(A_{t}^{i}\right)^{\mu}\left(1+z_{t}\right)^{1-\mu}
\end{gathered}
$$

Assume that the outsourcing contract is one featuring revenue-sharing. More specifically, the value of the contracted manufacturing output is so divided that a fraction $\phi$ goes to the local country with the remaining fraction to the source country.

The Bellman equation facing the representative manufacturer is now given by,

$$
\begin{gathered}
W^{O S}\left(A_{t}^{i}\right)=\max _{z_{t}}\left[(1-\phi) p_{t}^{i} A_{t}^{i}\left(K_{t}^{M}\right)^{\gamma}-q_{t} z_{t}\right]+\frac{1}{1+r} W^{O S}\left(A_{t+1}^{i}\right) \\
\text { s.t. } \quad A_{t+1}^{i}=\psi\left(A_{t}^{i}\right)^{\mu}\left(1+z_{t}\right)^{1-\mu}
\end{gathered}
$$

Compared to the exporting regime, the production technology under the outsourcing regime is unambiguously higher due to complete specialization by devoting the entirety of the general capital to research $(s=1)$. Yet, the associated profit can be higher (as a result of using a better technology) or lower (if the local country's supply of capital is scarce or if the cost of revenue-sharing outweighs the technology gain).

The first-order condition and the Benveniste-Scheinkman condition are:

$$
\begin{gathered}
\frac{1}{1+r} \frac{\partial W^{O S}\left(A_{t+1}^{i}\right)}{\partial A_{t+1}^{i}}(1-\mu) \psi\left(A_{t}^{i}\right)^{\mu}\left(1+z_{t}\right)^{-\mu}=q_{t} \\
\frac{\partial W^{O S}\left(A_{t}^{i}\right)}{\partial A_{t}^{i}}=(1-\phi) p_{t}^{i}\left(K_{t}^{M}\right)^{\gamma}+\frac{1}{1+r} \frac{\partial W^{O S}\left(A_{t+1}^{i}\right)}{\partial A_{t+1}^{i}} \mu \psi\left(A_{t}^{i}\right)^{\mu-1}\left(1+z_{t}\right)^{1-\mu}
\end{gathered}
$$

\subsection{Local Country}

We assume that capital in the less developed local economy is of "low quality" in the sense that it can only be used for manufacturing purposes. So, without research capital or spending on R\&D (which we rule out) $A_{t}^{j}=0$ and the manufactured good cannot be produced by the local company without help from the source country. Denote the aggregate capital stock in the local country at 
the beginning of time $t$ as $K_{t}$. Then, capital may be devoted to production of the necessity or production of the outsourced manufactured good.

$$
K_{t}=K_{t}^{N}+K_{t}^{M}
$$

The entire stock depreciates at a rate $\delta \in(0,1)$ and is augmented by gross investment $v_{t}$, thus evolving according to:

$$
K_{t+1}=(1-\delta) K_{t}+v_{t}
$$

This evolution process is modeled explicitly because it is the only force of growth to the local economy in transition to the steady state.

The production of the necessity takes the simple Cobb-Douglas form:

$$
N_{t}=\left(K_{t}^{N}\right)^{\beta}
$$

where $\beta \in(0,1)$. The output of the necessity will be partly consumed by the local economy (call this fraction $\eta$ ) and partly exported to the world market (fraction $1-\eta$ ) at fixed price one.

Denote the subjective time discount rate as $\rho>0$. The periodic utility of the representative consumer-producer (of a given ideal taste type $i$ ) purchasing manufactured goods of variety $j$ is specified as (index $i$ dropped for notational convenience whenever it does not create any confusion):

$$
U^{i}\left(N_{t}^{d}, M_{t}^{j}\right)=\ln \left(N_{t}^{d}\right)+\ln \left(\theta+\Gamma^{j} M_{t}^{j}\right)
$$

where $N_{t}^{d}$ measures the local demand for the necessity, $\theta>0$ indicates that the manufactured good is not a necessity, and $\Gamma^{j} \leq 1$ captures preference bias toward the ideal variety. Assume $\Gamma^{j}=1-\left(\frac{\Gamma_{0}}{[J / 2]}\right) d^{j}$, where $d^{j}$ denotes the minimum distance between the purchased variety $j$ and the ideal variety $i,[\cdot]$ is the Gauss operator, and $\Gamma_{0} \in(0,1)$. Obviously, when the purchased variety $j$ is the ideal variety $i$ (which occurs only when the manufactured good is outsourced), we have $\Gamma^{i}=1$. Otherwise, there is "variety-specific preference discounting" at a factor $\Gamma^{j}<1(j \neq i)$. The larger $\Gamma_{0}$ or $d^{j}$, the greater the variety-specific preference discount.

Let $Y_{t}$ denote the periodic income in units of the necessity good (to be specified later). The representative consumer-producer's intertemporal budget constraint is given by,

$$
N_{t}^{d}+p_{t}^{j} M_{t}^{j}+v_{t}=Y_{t}
$$

which together with (15) implies,

$$
K_{t+1}-K_{t}=Y_{t}-\delta K_{t}-N_{t}^{d}-p_{t}^{j} M_{t}^{j}
$$




\subsubsection{Importing the manufactured good}

When the manufactured good is produced in the source country, the optimization problem facing the local country's representative agent is simple: maximize lifetime utility by allocating intertemporally available resources to consumption of one (the necessity) or both goods and capital investment. In this case, the variety $j$ of the manufactured good provided to the local economy is given in the absence of outsourcing. Thus, we have: $K_{t}^{N}=K_{t}, K_{t}^{M}=0$, and $Y_{t}=\left(K_{t}\right)^{\beta}$.

Given the discount rate $\rho>0$, the Bellman equation facing the representative agent in the case where the manufactured good is produced in the source country and exported is given by,

$$
\begin{gathered}
V^{E X}\left(K_{t}\right)=\max _{N_{t}^{d}, M_{t}^{j}}\left\{\ln \left(N_{t}^{d}\right)+\ln \left(\theta+\Gamma^{j} M_{t}^{j}\right)\right\}+\frac{1}{1+\rho} V^{E X}\left(K_{t+1}\right) \\
\text { s.t. } \quad K_{t+1}=\left(K_{t}\right)^{\beta}+(1-\delta) K_{t}-N_{t}^{d}-p_{t}^{j} M_{t}^{j}
\end{gathered}
$$

The first-order conditions for $N_{t}^{d}$ and $M_{t}^{j}$ equate the respective marginal utility with the associated shadow price,

$$
\begin{aligned}
\frac{1}{N_{t}^{d}} & =\frac{1}{1+\rho} \frac{d V^{E X}\left(K_{t+1}\right)}{d K_{t+1}} \\
\frac{\Gamma^{j}}{\theta+\Gamma^{j} M_{t}^{j}} & =\frac{1}{1+\rho} \frac{d V^{E X}\left(K_{t+1}\right)}{d K_{t+1}} p_{t}^{j}
\end{aligned}
$$

Given $\theta>0$, the lower the variety-specific preference discounting (higher $\Gamma^{j}$ ), the greater the marginal utility of consuming the manufactured good (the LHS of (21)). Should the luxurious nature of the manufactured good disappear $(\theta=0)$, the variety-specific preference discounting will no longer influence the consumption behavior.

The Benveniste-Scheinkman condition is:

$$
\frac{d V^{E X}\left(K_{t}\right)}{d K_{t}}=\frac{1}{1+\rho} \frac{d V^{E X}\left(K_{t+1}\right)}{d K_{t+1}}\left[\beta\left(K_{t}\right)^{\beta-1}+(1-\delta)\right]
$$

\subsubsection{Producing the outsourced manufactured good}

When the manufactured good is produced in the local economy via outsourcing, the optimization problem facing the local country's representative agent has to include the allocation of capital between the two sectors (provided that accepting the outsourcing contract is profitable). With the local economy's involvement, it is assumed that the ideal variety $i$ of the manufactured good can be identified. In this case, $K_{t}^{M}=K_{t}-K_{t}^{N}, N_{t}=\left(K_{t}^{N}\right)^{\beta}, M_{t}^{i}=A_{t}^{i}\left(K_{t}-K_{t}^{N}\right)^{\gamma}$, and

$$
Y_{t}=\left(K_{t}^{N}\right)^{\beta}+\phi p_{t}^{i} A_{t}^{i}\left(K_{t}-K_{t}^{N}\right)^{\gamma}
$$


That is, real income accrued to the local country now depends on two sources, both from producing the necessity and from revenue sharing by producing the manufactured good.

The Bellman equation facing the representative agent in this outsourcing case now becomes:

$$
\begin{aligned}
& V^{O S}\left(K_{t}\right)=\max _{N_{t}^{d}, M_{t}^{i}, v_{t}}\left\{\ln \left(N_{t}^{d}\right)+\ln \left(\theta+M_{t}^{i}\right)\right\}+\frac{1}{1+\rho} V^{O S}\left(K_{t+1}\right) \\
& \text { s.t. } \quad K_{t+1}=\left(K_{t}^{N}\right)^{\beta}+\phi p_{t}^{i} A_{t}^{i}\left(K_{t}-K_{t}^{N}\right)^{\gamma}+(1-\delta) K_{t}-N_{t}^{d}-p_{t}^{i} M_{t}^{i}
\end{aligned}
$$

The first-order conditions are:

$$
\begin{aligned}
\frac{1}{N_{t}^{d}} & =\frac{1}{1+\rho} \frac{d V^{O S}\left(K_{t+1}\right)}{d K_{t+1}} \\
\frac{1}{\theta+M_{t}^{i}} & =\frac{1}{1+\rho} \frac{d V^{O S}\left(K_{t+1}\right)}{d K_{t+1}} p_{t}^{i} \\
\beta\left(K_{t}^{N}\right)^{\beta-1} & =\gamma \phi p_{t}^{i} A_{t}^{i}\left(K_{t}-K_{t}^{N}\right)^{\gamma-1}
\end{aligned}
$$

We note that the first-order condition with respect to $M_{t}^{i}(26)$ differs from (21) under the exporting regime because there is no variety-specific preference discounting under outsourcing. Also in contrast with the previous case, there is an additional first order condition (27) that governs optimal capital allocation between the two sectors.

The Benveniste-Scheinkman condition is:

$$
\frac{d V^{O S}\left(K_{t}\right)}{d K_{t}}=\frac{1}{1+\rho} \frac{d V^{O S}\left(K_{t+1}\right)}{d K_{t+1}}\left[\gamma \phi p_{t}^{i} A_{t}^{i}\left(K_{t}-K_{t}^{N}\right)^{\gamma-1}+(1-\delta)\right]
$$

\section{Equilibrium}

We next turn to the determination of equilibrium. Consider the following timing of events:

1. The source country determines whether to outsource production of the manufactured good to the local country with a revenue-sharing contract that rewards local country a fraction $\phi$ of the surplus accrued.

2. The local country decides whether to accept this outsourcing contract, if offered.

3. Under the exporting or the outsourcing regime, the source country and the local country determine optimal allocations and the equilibrium relative price of the manufactured good is 
determined as follows.

$$
\begin{aligned}
(\mathrm{EX}) p_{t}^{j} & =\frac{\Gamma^{j} N_{t}^{d}}{\theta+\Gamma^{j} M_{t}^{j}}=\frac{\left(K_{t}\right)^{\beta} \eta_{t}}{\frac{\theta}{\Gamma^{j}}+A_{t}^{j}\left(1-s_{t}\right)^{\gamma}} \\
(\mathrm{OS}) p_{t}^{i} & =\frac{N_{t}^{d}}{\theta+M_{t}^{i}}=\frac{\left(K_{t}^{N}\right)^{\beta} \eta_{t}}{\theta+A_{t}^{i}\left(K_{t}-K_{t}^{N}\right)^{\gamma}}
\end{aligned}
$$

where $\eta_{t}$ is the share of $N_{t}$ that is consumed in the local country. ${ }^{2}$

Next, we solve for the equilibrium. To satisfy subgame perfection, we solve the problem backward. Before solving the model, however, it is useful to provide a brief comparison between the two market prices of the manufactured goods in units of the necessity. From (29) and (30), there

\begin{tabular}{|c|c|}
\hline & $p^{j} \quad$ vs. $\quad p^{i}$ \\
\hline (1) $\Gamma^{j}<1$ & $<$ \\
\hline (2) $K^{N}<K$ & $>$ \\
\hline (3) $A^{j}<A^{i}$ & $>$ \\
\hline (4) $H^{M}$ vs. $K^{M}$ & $?$ \\
\hline
\end{tabular}
are four channels through which the two manufactured good prices may differ:

The first channel is through variety-specific preference bias. Since the imported manufactured good is less preferred than the locally produced one (under the outsourcing regime) there is less demand and a lower market price, thus $\Gamma^{j}<1$ implies $p^{j}<p^{i}$. Second, by importing the manufactured good, the local economy can focus exclusively on producing the necessity and greater supply of the necessity leads to a higher relative price of the manufactured good. Third, by exporting the manufactured good, the source country's economy must allocate a portion of capital to its' production. Thus, less capital is allocated to research leading to a slower rate of technological advancement. This in turns lowers the productivity and hence the supply of manufactured good, leading to a higher relative price of the exported manufactured good. Finally, the supply of the manufactured good also depends on the factor input: $H^{M}=1-s$ versus $K^{M}=K-K^{N}$. Even by assuming that the more advanced source country is capital abundant, it is not clear its productionuse capital is larger than the counterpart in the less developed local country. Thus, the effect on the market prices is ambiguous.

In summary, while variety-specific preference bias tends to make the relative price of the manufactured good under the exporting regime lower than under the outsourcing regime, outsourcingdriven production specialization both in the local economy $\left(K^{N}<K\right)$ and in the source country

\footnotetext{
${ }^{2}$ It follows that $\left(1-\eta_{t}\right)$ of the necessity good will be exported by the local country.
} 
$\left(A^{j}<A^{i}\right)$ leads to the opposite outcome. Thus, even without accounting for relative capital abundance $\left(H^{M}\right.$ vs. $\left.K^{M}\right)$, the offsetting demand and supply forces yields inconclusive results regarding the relative price of the manufactured good under the two regimes. We now proceed to solving for the equilibrium.

\subsection{Stage 3}

We will first derive the steady-state solutions in each of the two regimes: exporting and outsourcing.

\subsubsection{The Exporting Regime}

Under the exporting regime,we can manipulate the first-order conditions and the BenvenisteScheinkman condition, (6), (7) and (8), to obtain:

$$
\begin{gathered}
\gamma p_{t}^{j} A_{t}^{j}\left(1-s_{t}\right)^{\gamma-1}=q_{t} \\
\frac{p_{t}^{j}}{p_{t-1}^{j}}=\frac{(1+r) \gamma\left(A_{t-1}^{j}\right)^{1-\mu}\left(s_{t}+z_{t}\right)^{\mu}}{(1-\mu) \psi\left(1-s_{t-1}\right)^{1-\gamma}\left(1-s_{t}\right)^{\gamma}\left(1+\gamma \frac{\mu}{1-\mu} \frac{s_{t}+z_{t}}{1-s_{t}}\right)}
\end{gathered}
$$

Moreover, from (20) and (22), we have:

$$
\begin{gathered}
p_{t}^{j}\left(\theta+\Gamma^{j} M_{t}^{j}\right)=\Gamma^{j} \eta_{t} N_{t} \\
\eta_{t} N_{t}=\frac{\eta_{t-1} N_{t-1}}{1+\rho}\left[\beta\left(K_{t}\right)^{\beta-1}+(1-\delta)\right]
\end{gathered}
$$

Imposing the steady state, (31), (32) and (34) become:

$$
\begin{aligned}
p^{j} A^{j}(1-s)^{\gamma} & =\frac{q}{\gamma}(1-s) \\
(1+r) \gamma\left(A^{j}\right)^{1-\mu}(s+z)^{\mu} & =\psi[(1-\mu)(1-s)+\gamma \mu(s+z)] \\
\beta(K)^{\beta-1} & =\delta+\rho
\end{aligned}
$$

The expression in (37) is the standard modified golden rule in discrete-time neoclassical growth models, which alone pins down the steady-state value of capital in the local economy: $\bar{K}=$ $\left(\frac{\beta}{\delta+\rho}\right)^{\frac{1}{1-\beta}}$. From (15) and $(18), v=\delta \bar{K}$ and $p^{j} M^{j}+\delta \bar{K}=(1-\eta) Y$. This latter relationship, together with the production functions, (4) and (16), implies: $p^{j} A^{j}(1-s)^{\gamma}+\delta \bar{K}=(1-\eta)(\bar{K})^{\beta}$, which can be further combined with (35) to yield:

$$
\frac{q}{\gamma}(1-s)=(\bar{K})^{\beta}(1-\eta)-\delta \bar{K}=\left[\frac{\delta+\rho}{\beta}(1-\eta)-\delta\right] \bar{K}
$$


or,

$$
s=1-\frac{\gamma}{q}\left[\frac{\delta+\rho}{\beta}(1-\eta)-\delta\right] \bar{K}
$$

That is, a higher export share of the necessity in the local economy $(1-\eta)$ makes the local economy richer and demand higher for the manufactured good, which in turn encourages the source country to allocate general capital to production $(1-s)$. In other words, the share of production-use general capital in the source country and the export share of the necessity in the local country are positively related. This relationship is referred to as the exportable production $(X P)$ locus; see the bottom panel of Figure 1.

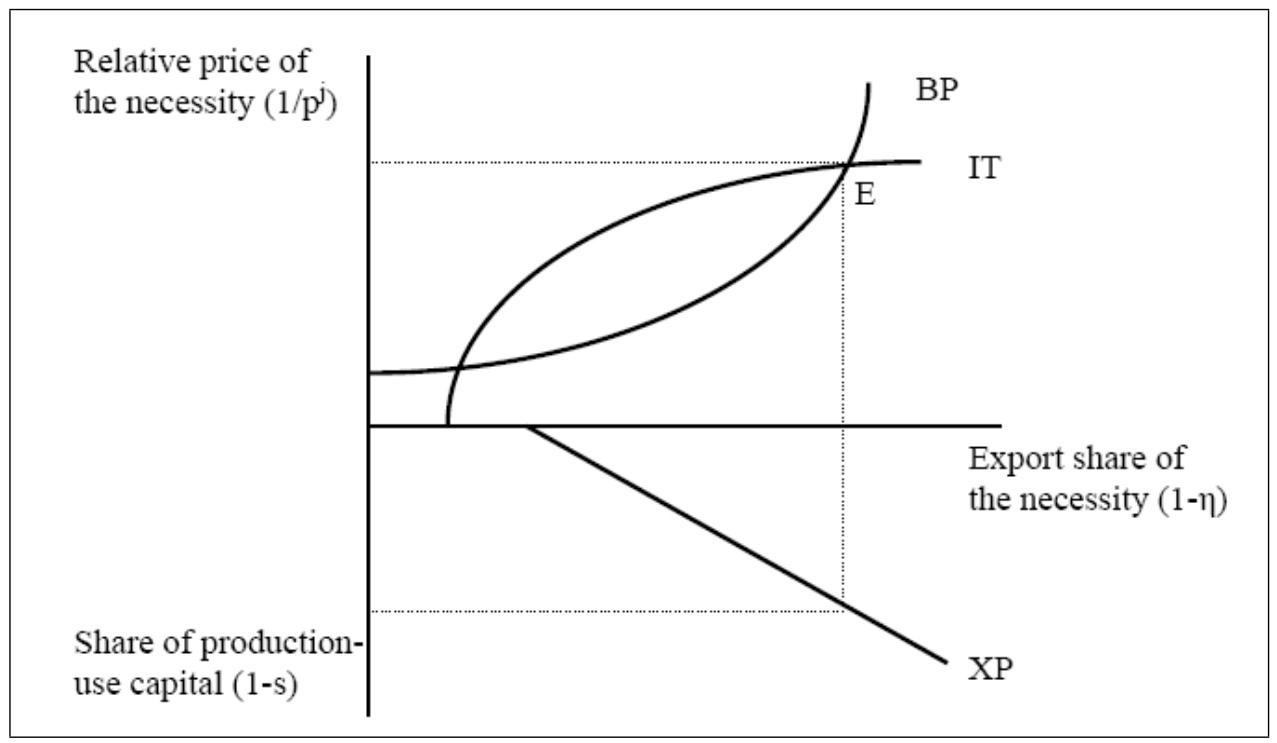

Figure 1: Allocation and Pricing in the Exporting Regime (EX)

From $(3), A^{j}=\psi^{\frac{1}{1-\mu}}(s+z)$, which can be substituted into (36) to derive $\gamma(1-\mu+r)(s+z)=$ $(1-\mu)(1-s)$, or,

$$
z=\frac{(1-\mu)-[(1-\mu)+\gamma(1-\mu+r)] s}{\gamma(1-\mu+r)}
$$

Thus, the steady-state level of technology is given by,

$$
A^{j}=\frac{\psi^{\frac{1}{1-\mu}}(1-\mu)}{\gamma(1-\mu+r)}(1-s)
$$

Intuitively, more allocation of general capital to $R \& D$ substitutes for $R \& D$ investment. Because an increase in $s$ decreases $z$ more than proportionately, it results in a net reduction in the steady-state level of technology. ${ }^{3}$

\footnotetext{
${ }^{3}$ More precisely, $\frac{d z}{d s}=-\frac{(1-\mu)+\gamma(1-\mu+r)}{\gamma(1-\mu+r)}<-1$.
} 
We next combine (35), (38) and (41) to obtain:

$$
\frac{1}{p^{j}}=B_{0}(\bar{K})^{\gamma}\left[\frac{\delta+\rho}{\beta}(1-\eta)-\delta\right]^{\gamma}
$$

where $B_{0}=\frac{1-\mu}{1-\mu+r} \frac{\gamma^{\gamma} \psi^{\frac{1}{1-\mu}}}{q^{1+\gamma}}>0$. This gives a positive relationship between the relative price of the necessity $\left(\frac{1}{p^{j}}\right)$ and the the export share of the necessity. This relationship is based on the budget constraint and the intertemporal trade-off between current production and technological advancement. We therefore refer to it as the intertemporal trade locus (IT). It is straightforward to show that the $I T$ locus is not only increasing but strictly concave in $\left(1-\eta, 1 / p^{j}\right)$ space, with a horizontal intercept, $\frac{\delta \beta}{\rho+\delta}$.

Moreover, we can substitute (35) into (33) (imposing the steady state) and utilize (38) to get:

$$
\frac{1}{p^{j}}=\frac{\theta}{\Gamma^{j}\left[\delta \bar{K}+(\bar{K})^{\beta}-2(\bar{K})^{\beta}(1-\eta)\right]}=\frac{\theta}{\Gamma^{j} \bar{K}\left[\delta+\frac{\delta+\rho}{\beta}-2 \frac{\delta+\rho}{\beta}(1-\eta)\right]}
$$

This gives another positive relationship between the relative price of the necessity and the export share of the necessity. This relationship follows from the budget constraint and the marginal rate of substitution conditions. We can think of this as the balance of payments condition and is hence referred to as the balance of payments locus $(B P)$. The $B P$ locus is strictly increasing and strictly convex in $\left(1-\eta, 1 / p^{j}\right)$ space, with an asymptote, $1-\eta=\frac{\delta+\frac{\delta+\rho}{\beta}}{2 \frac{\delta+\rho}{\beta}}=\frac{\delta \beta}{\rho+\delta}+\frac{\rho+\delta(1-\beta)}{2(\rho+\delta)}>\frac{\delta \beta}{\rho+\delta}$.

Intuitively, the $B P$ locus may simply be viewed as the local country's supply curve of the necessity embedded with optimal consumption allocation and trade balance conditions. Thus, it is not surprising that the $B P$ locus slopes upward. The IT locus is somewhat harder to explain. Precisely, it is a combination of the intertemporal consumption-capital choice by the local country and the intratemporal capital allocation and R\&D investment by the source country. Thus, the $I T$ locus does not represent the source country's demand for the necessity and need not be downwardsloping.

Under some regularity conditions, the $I T$ and the $B P$ loci intersect twice, yielding two steadystate solutions (see the top panel of Figure 1). By numerical exercises (see Section 3.4 below), we find that the low stationary point never arises in equilibrium as it violates some feasibility conditions (particularly, the non-negativity constraint of the production-use general capital). Thus, we will focus exclusively on the high stationary point (point $E$ in the top panel of Figure 1) around which we now perform comparative statics. 


\begin{tabular}{l|ll|lllll}
\hline Changes in & $B P$ locus & $I T$ locus & $1-\eta$ & $p^{j}$ & $s$ & $A^{j}$ & $z$ \\
\hline decrease in $\Gamma^{j}$ & upward shift & no change & - & + & + & - & - \\
or increase in $\theta$ & & & & & & & \\
increase in $\psi$ & no change & upward shift & + & - & - & + & + \\
\hline
\end{tabular}

In response to a greater variety-specific preference bias (due to a reduction in $\Gamma_{0}$ or $d^{j}$ ) or a greater preference bias away from the manufactured good (due to an increase in $\theta$ ), the $B P$ locus shifts up whereas the IT locus remains unchanged. As a result, the demand for the manufactured good in the local economy falls and the export share of the necessity increases. Due to a reduced valuation of the manufactured good, the value of marginal product of general capital in production decreases and the general capital stock is reallocated from manufacturing to research. However, the value of technological advancements is also lower, which results in less R\&D investment. On balance, the steady-state level of technology is lower (the negative effect via $z$ outweighs the positive effect via $s$ ). Both lower technology and lower production-use general capital lead to a lower supply of the manufactured good and hence less export this good to the local country. This supply effect turns out to dominate the demand effect (because the local country lacks the option to produce the manufactured good) and the equilibrium price of the manufactured good rises.

In response to more productive $\mathrm{R} \& \mathrm{D}$, (represented by an increase in $\psi$ ), the $I T$ locus shifts up whereas the $B P$ locus remains unchanged. Thus, the level of technology is higher and the value of technological advancements also rises, thereby increasing the R\&D investment. By substitution, the latter enables more general capital to be reallocated to production. As a result of both better technology and more general capital input, the supply of the manufactured good by the source firm increases, which subsequently lowers the relative price of the manufactured good and encourages the local economy to substitute the necessity by the manufactured good which leads to a higher export share of the necessity.

\subsubsection{The Outsourcing Regime}

Analogously, under the outsourcing regime, we can use (12) and (13) to derive:

$$
p_{t}^{i}=\frac{\mu}{1-\mu}\left[\frac{1+r}{\mu \psi}\left(\frac{1+z_{t-1}}{A_{t-1}^{i}}\right)^{\mu} q_{t-1}-\frac{1+z_{t}}{A_{t}^{i}} q_{t}\right] \frac{\left(K_{t}-K_{t}^{N}\right)^{\gamma}}{1-\phi}
$$

and use (25), (26), (27) and (28) to get:

$$
p_{t}^{i}\left(\theta+M_{t}^{i}\right)=\eta_{t} N_{t}
$$




$$
\begin{gathered}
\eta_{t} N_{t}=\frac{\eta_{t-1} N_{t-1}}{1+\rho}\left[\beta\left(K_{t}^{N}\right)^{\beta-1}+(1-\delta)\right] \\
\beta\left(K_{t}^{N}\right)^{\beta-1}=\gamma \phi p_{t}^{i} A_{t}^{i}\left(K_{t}-K_{t}^{N}\right)^{\gamma-1}
\end{gathered}
$$

Note that (45) is a special case of (33) with no variety preference discount (as $\Gamma^{i}=1$ ).

Imposing the steady state condition, we repeat the same steps, using (46) to obtain the modified golden rule:

$$
\beta\left(K_{t}^{N}\right)^{\beta-1}=\rho+\delta
$$

which yield the steady-state value of capital allocated to the production of the necessity: $\bar{K}^{N}=$ $\left(\frac{\beta}{\delta+\rho}\right)^{\frac{1}{1-\beta}}$. We then utilize (48) together with the production functions, (4) and (16), to write (45) and (47) as:

$$
\begin{aligned}
p^{i} \theta+p^{i} A^{i}\left(K-\bar{K}^{N}\right)^{\gamma} & =\eta\left(\bar{K}^{N}\right)^{\beta}=\frac{\rho+\delta}{\beta} \bar{K}^{N} \eta \\
p^{i} A^{i}\left(K-\bar{K}^{N}\right)^{\gamma-1} & =\frac{\rho+\delta}{\gamma \phi}
\end{aligned}
$$

which can be combined to yield:

$$
p^{i} \theta+\frac{\rho+\delta}{\gamma \phi}\left(K-\bar{K}^{N}\right)=\frac{\rho+\delta}{\beta} \bar{K}^{N} \eta
$$

From (15) and (18), we have: $v=\delta K$ and $(1-\phi) p^{i} M^{i}+\delta K=(1-\eta) N$, This latter expression, together with (4), (16), (23), (48) and (50), implies:

$$
K-\bar{K}^{N}=\bar{K}^{N}\left[\frac{\frac{\rho+\delta}{\beta}(1-\eta)-\delta}{\frac{1-\phi}{\phi} \frac{\rho+\delta}{\gamma}+\delta}\right] \text { and } K=\frac{\rho+\delta}{\beta} \bar{K}^{N}\left[\frac{\frac{1-\phi}{\phi} \frac{\beta}{\gamma}+(1-\eta)}{\frac{1-\phi}{\phi} \frac{\rho+\delta}{\gamma}+\delta}\right]
$$

Substituting (52) into (51), we obtain a fundamental steady-state relationship, which is the $B P$ locus under outsourcing:

$$
\frac{1}{p^{i}}=\frac{\beta \theta}{(\rho+\delta) \bar{K}^{N}}\left[B_{1}-B_{2}(1-\eta)\right]^{-1}
$$

where $B_{1}=1+\frac{\beta}{\gamma \phi} \frac{\delta}{\frac{1-\phi}{\phi} \frac{\rho+\delta}{\gamma}+\delta}>1$ and $B_{2}=1+\frac{\frac{\rho+\delta}{\gamma \phi}}{\frac{1-\phi}{\phi} \frac{\rho+\delta}{\gamma}+\delta}>1$. This $B P$ locus has a similar shape to that under the export regime, which is strictly increasing and strictly convex in $\left(1-\eta, 1 / p^{j}\right)$ space, with an asymptote, $1-\eta=\frac{B_{1}}{B_{2}}=\frac{\frac{1-\phi}{\phi} \frac{\rho+\delta}{\gamma}+\delta+\frac{\delta \beta}{\gamma \phi}}{\frac{1-\phi}{\phi} \frac{\rho+\delta}{\gamma}+\delta+\frac{\rho+\delta}{\gamma \phi}}>\frac{\delta \beta}{\rho+\delta}$.

Now, from (10) and imposing the steady state, we have:

$$
A^{i}=\psi^{\frac{1}{1-\mu}}(1+z)
$$


By applying (48), (54) and (54), (44) in the steady state can be rewritten as:

$$
\frac{1}{p^{i}}=\frac{(1-\mu)(1-\phi) \psi^{\frac{1}{1-\mu}}}{(1-\mu+r) q\left(\bar{K}^{N}\right)^{\gamma}}\left[\frac{\frac{\rho+\delta}{\beta}(1-\eta)-\delta}{\frac{1-\phi}{\phi} \frac{\rho+\delta}{\gamma}+\delta}\right]^{-\gamma}
$$

which is the IT locus under outsourcing. Unlike the exporting case, the IT locus for outsourcing is downward-sloping and strictly convex in $\left(1-\eta, 1 / p^{j}\right)$ space, with an asymptote, $1-\eta=\frac{\delta \beta}{\rho+\delta}$. The outsourcing equilibrium is illustrated in Figure 2.

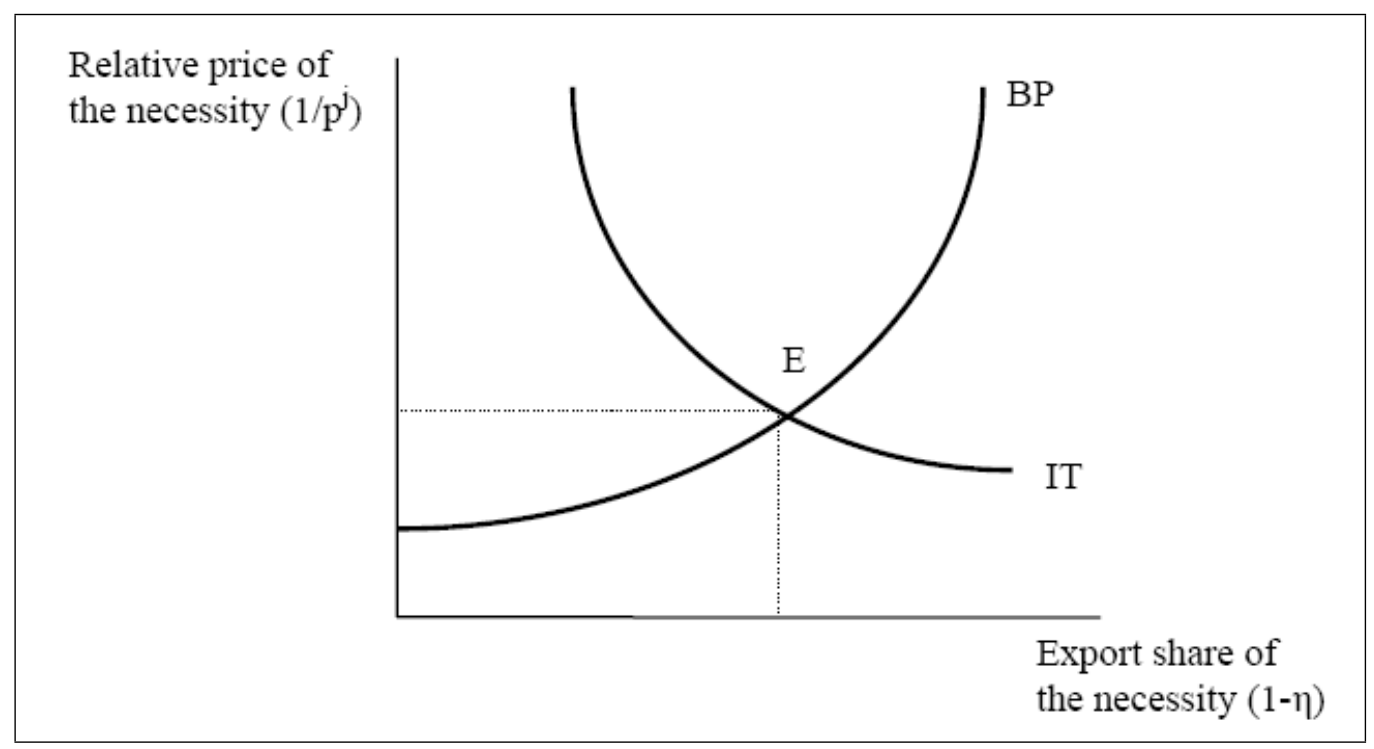

Figure 2: Allocation and Pricing in the Outsourcing Regime (OS)

Next, we obtain:

$$
\begin{aligned}
A^{i} & =\frac{\rho+\delta}{\gamma \phi}\left(\bar{K}^{N}\right)^{1-\gamma}\left[\frac{\frac{\rho+\delta}{\beta}(1-\eta)-\delta}{\frac{1-\phi}{\phi} \frac{\rho+\delta}{\gamma}+\delta}\right]^{1-\gamma} \frac{1}{p^{i}} \\
1+z & =\psi^{\frac{-1}{1-\mu}} \frac{\rho+\delta}{\gamma \phi}\left(\bar{K}^{N}\right)^{1-\gamma}\left[\frac{\frac{\rho+\delta}{\beta}(1-\eta)-\delta}{\frac{1-\phi}{\phi} \frac{\rho+\delta}{\gamma}+\delta}\right]^{1-\gamma} \frac{1}{p^{i}}
\end{aligned}
$$

The comparative statics can be summarized as follows.

\begin{tabular}{l|cc|ccccc}
\hline$(\mathrm{OS})$ & $B P$ locus & $I T$ locus & $1-\eta$ & $p^{j}$ & $K$ & $A^{j}$ & $z$ \\
\hline increase in $\theta$ & upward shift & no change & - & - & - & $?$ & $?$ \\
increase in $\psi$ & no change & upward shift & + & - & + & + & $?$ \\
\hline
\end{tabular}


In response to a preference shift away from the manufactured good (due to an increase in $\theta$ ), the $B P$ locus shifts up whereas the $I T$ locus remains unchanged. As a result, the demand for the manufactured good in the local economy is lower, the export share of the necessity is lower, and the relative price of the manufactured good falls. While the total stock of capital falls due to reduced input into manufacturing the outsourced good (the capital input in the traditional sector remains unchanged), the opposing forces cause ambiguous effects on $A^{j}$ and $z$.

In response to more productive $\mathrm{R} \& \mathrm{D}$ (represented by an increase in $\psi$ ), the $I T$ locus shifts up whereas the $B P$ locus remains unchanged. Thus, local capital is reallocated from the production of the necessity to the production of the outsourced manufactured good, causing the relative price of the manufactured good to fall, the local consumption of the necessity to decrease and hence the export share of the necessity increases. The total stock of capital increases as a result of more induced demand to manufacture the outsourced good. The steady-state level of technology is unambiguously higher in the absence of sectoral allocation effects in the source country $(s=1)$. The effect on the investment in $\mathrm{R} \& \mathrm{D}$, is ambiguous as higher productivity leads to more investment in $R \& D$ via the substitution effect, but less investment due to the factor-saving effect of the better technology.

\subsection{Stage 2}

We turn next to examining whether the representative consumer-producer in the local economy would accept the outsourcing contract. This decision depends on the comparison of the respective value function facing the representative local agent under each regime, which in the steady state can be expressed as:

$$
\begin{aligned}
W^{E X} & =\frac{1+\rho}{\rho}\left[\ln \left(N_{t}^{d}\right)+\ln \left(\theta+\Gamma^{j} M^{j}\right)\right] \\
W^{O S} & =\frac{1+\rho}{\rho}\left[\ln \left(N_{t}^{d}\right)+\ln \left(\theta+M^{i}\right)\right]
\end{aligned}
$$

Using results derived in Stage 3, we have:

$$
\begin{aligned}
W^{E X} & =\frac{1+\rho}{\rho}\left[\ln \left(\eta^{E X}\right)+\frac{\beta}{1-\beta} \ln \left(\frac{\beta}{\delta+\rho}\right)+\ln \left(\theta+\Gamma^{j}\left(A^{j}\right)^{E X}\left(1-s^{E X}\right)^{\gamma}\right)\right] \\
& =\frac{1+\rho}{\rho}\left[\ln \left(\eta^{E X}\right)+\frac{\beta}{1-\beta} \ln \left(\frac{\beta}{\delta+\rho}\right)+\ln \left\{\theta+\frac{\Gamma^{j} \bar{K}}{\left(p^{j}\right)^{E X}}\left[\frac{\delta+\rho}{\beta}\left(1-\eta^{E X}\right)-\delta\right]\right\}\right]
\end{aligned}
$$




$$
\begin{aligned}
W^{O S} & =\frac{1+\rho}{\rho}\left[\ln \left(\eta^{O S}\right)+\frac{\beta}{1-\beta} \ln \left(\frac{\beta}{\delta+\rho}\right)+\ln \left(\theta+\left(A^{i}\right)^{O S}\left(K^{O S}-\bar{K}^{N}\right)^{\gamma}\right)\right] \\
& =\frac{1+\rho}{\rho}\left[\ln \left(\eta^{O S}\right)+\frac{\beta}{1-\beta} \ln \left(\frac{\beta}{\delta+\rho}\right)+\ln \left\{\theta+\frac{(\rho+\delta) \bar{K}^{N}}{\gamma \phi\left(p^{i}\right)^{O S}}\left[\frac{\frac{\rho+\delta}{\beta}\left(1-\eta^{O S}\right)-\delta}{\frac{1-\phi}{\phi} \frac{\rho+\delta}{\gamma}+\delta}\right]\right\}\right]
\end{aligned}
$$

When the source country deals with a low-income country, the local economy's export share of the necessity is low and thus, the associated consumption share $\left(\eta^{E X}\right)$ is high. Due to high discounting $(\rho)$, the steady-state value of capital $(\bar{K})$ is low. Thus, the direct consumption effect via the first term of the value function dominates the indirect trade effect via the third term, making the local agent more likely to import the manufactured good $\left(M^{j}\right)$ than accepting an outsourcing contract. Moreover, the less desirable the manufactured good is, the smaller the gap between the willingness to pay for an ideal variety and the reference variety $j$. That is, $\left(p^{i}\right)^{O S}-\left(p^{j}\right)^{E X}$ is low. This will be crucial for the next stage to which we now turn.

\subsection{Stage 1}

Finally, we determine whether the representative firm in the source country would choose outsourcing of the manufactured good over exporting. This is determined by comparing the respective value function facing the representative source country agent under each regime, which in the steady state can be expressed as:

$$
\begin{aligned}
V^{E X} & =\frac{1+r}{r}\left[p^{j} A^{j}(1-s)^{\gamma}-q z\right] \\
V^{O S} & =\frac{1+r}{r}\left[(1-\phi) p^{i} A^{i}\left(K-\bar{K}^{N}\right)^{\gamma}-q z\right]
\end{aligned}
$$

Again, we can utilize results derived in Stage 3 to obtain:

$$
\begin{gathered}
V^{E X}=\frac{1+r}{r}\left\{\left[\frac{\delta+\rho}{\beta}(1-\eta)-\delta\right] \bar{K}-q z\right\} \\
=\frac{1+r}{r}\left\{q+\left[\frac{r-\gamma(1-\mu+r)}{1-\mu+r}\right] R(1-\eta)\right\} \\
V^{O S}=\frac{1+r}{r}\left[(1-\phi) p^{i} A^{i}\left(K-\bar{K}^{N}\right)^{\gamma}-q z\right] \\
=\frac{1+r}{r}\left\{(1-\phi) \frac{\rho+\delta}{\gamma \phi} \bar{K}^{N}\left[\frac{\frac{\rho+\delta}{\beta}(1-\eta)-\delta}{\frac{1-\phi}{\phi} \frac{\rho+\delta}{\gamma}+\delta}\right]+q-q \psi^{\frac{-1}{1-\mu}} \frac{\rho+\delta}{\gamma \phi} \frac{1}{p^{i}}\left[\bar{K}^{N} \frac{\frac{\rho+\delta}{\beta}(1-\eta)-\delta}{\frac{1-\phi}{\phi} \frac{\rho+\delta}{\gamma}+\delta}\right]^{1-\gamma}\right\} \\
=\frac{1+r}{r}\left\{q+(1-\phi) R^{O S}(1-\eta)-q \psi^{\frac{-1}{1-\mu}}\left(\frac{\rho+\delta}{\gamma \phi}\right)^{\gamma} \frac{1}{p^{i}}\left[R^{O S}(1-\eta)\right]^{1-\gamma}\right\}
\end{gathered}
$$


where $R^{E X}(1-\eta)=\bar{K}\left[\frac{\delta+\rho}{\beta}(1-\eta)-\delta\right]$ and $R^{O S}(1-\eta)=\frac{\rho+\delta}{\gamma \phi} \bar{K}^{N}\left[\frac{\frac{\rho+\delta}{\beta}(1-\eta)-\delta}{\frac{1-\phi}{\phi} \frac{\rho+\delta}{\gamma}+\delta}\right]$, measuring steadystate revenue gained by the source country firm (both are an increasing in the local firm's export share of the necessity, $1-\eta)$.

Based on the results from Stage 2, $\left(p^{i}\right)^{O S}-\left(p^{j}\right)^{E X}$ is low in the case when the source country is dealing with a low-income country. In this case, the source country has less incentive to outsource. Thus, the source country will choose to produce and export the manufacture good, so the lowincome local country imports the manufactured good.

Without further specification of the bargaining between the source and the local countries, we can conclude:

\begin{tabular}{l|l}
\hline Equilibrium outcome & Conditions \\
\hline Exporting (EX) & $W^{E X}-W^{O S}>0$ and $V^{E X}-V^{O S}>0$ \\
Outsourcing (OS) & $W^{E X}-W^{O S}<0$ and $V^{E X}-V^{O S}<0$ \\
Indeterminate & $\left(W^{E X}-W^{O S}\right)\left(V^{E X}-V^{O S}\right)<0$ \\
\hline
\end{tabular}

\subsection{Numerical Analysis}

Since we cannot obtain an analytic solution for the equilibrium prices and allocations we turn to numerical analysis. Our benchmark parametrization is to set both the depreciation rate and the time discount rate at $\delta=\rho=5 \%$, the variety-specific preference discounting at $\Gamma^{j}=0.8$, and the real interest rate at $r=10 \%$. The output elasticities of capital are chosen to be $\beta=0.3$ and $\gamma=0.35$, implying the production of the manufactured good is more capital intensive than the production of the necessity. The technology parameters are set at $\psi=0.85$ and $\mu=0.9$, the real cost of $\mathrm{R} \& \mathrm{D}$ investment at $q=0.3$, and the preference bias parameter at $\theta=0.07$.

Then, if the equilibrium results in exporting of the manufactured good, the relative price of the manufactured good is $p^{j}=3.63$. The comparable figure under the outsourcing regime with $\phi=0.25$ is $p^{i}=3.30$. Thus, under the benchmark case, the supply effect dominates the demand effect.

The allocation under each regime are provided as follows.

\begin{tabular}{l|llllllll}
\hline Regime & $1-\eta$ & $s$ & $z$ & $A$ & $\frac{K^{M}}{K}$ & $N^{d}$ & $M$ & $\frac{N^{d}}{Y}$ \\
\hline EX & 0.476 & 0.391 & 0.479 & 0.171 & $0 \%$ & 0.839 & 0.144 & $52.4 \%$ \\
OS & 0.462 & 1 & 0.195 & 0.235 & $11.4 \%$ & 0.861 & 0.198 & $48.8 \%$ \\
\hline
\end{tabular}


Thus, under the outsourcing regime, the technology in the source country is far better, which generates a "trickle-down" effect via revenue-sharing, enabling the local country to consume more of both goods and to export more of its own products.

Next, we ask which regime arises in equilibrium? Using the benchmark parametrization, our numerical results suggest outsourcing occurs if (but not only if) $\phi \in(0.21143,0.33179)$. When $\phi$ (the fraction of output that goes to the host country under outsourcing) is too low, the local country desires to import the manufactured good despite the fact that the source country prefers to outsource. When $\phi$ is too high, the source country no longer offers outsourcing as an option but simply produces and exports the manufactured good. Should the local country feature a relatively high initial capital stock, there always exists a non-empty range of revenue-sharing schemes under our benchmark parametrization such that outsourcing can arise in the steady state. Of course, outsourcing may never arise if (i) local country capital is scarce (due to a sufficiently low initial capital stock or an insufficient accumulation of the capital stock as a result of a high time discount rate), (ii) local country income is low (due to a sufficiently low capital return associated with low $\beta$ ), or (iii) its consumers spend a major portion of their income on the necessity (due to a sufficiently high value of $\theta$ ).

\section{Conclusion}

We consider a model that focuses on the export/outsource decision. For the source country the advantage of outsourcing is that the host country partners have better information about local preferences, so the outsourcing outcome involves "design for manufacturing" to suit local preferences. The trade-off is that producing in the host country also means using the inferior technology embodied in the local capital. The decision of whether to offer an outsourcing contract weighs these two effects against each other. For the host country, they accept the outsourcing contract if the higher price they pay for the outsourced good is worth the benefit of consuming a manufactured good closer to their ideal variety. These results suggest that as the low income country develops they become a more attractive destination for outsourcing because the quality of their capital improves and the local market is more lucrative. In addition, the developing low income country finds the outsourcing contract more attractive since their increased demand for the correct variety of the manufactured good increases. This suggests that preference based outsourcing is more likely to occur with higher income host countries. 


\section{Appendix}

We list some useful expressions for computing values.

1. (EX):

$$
\begin{aligned}
M^{j} & =A^{j}(1-s)^{\gamma}, \\
N & =(\bar{K})^{\beta} \\
Y & =(\bar{K})^{\beta} \\
\bar{K} & =\left(\frac{\beta}{\delta+\rho}\right)^{\frac{1}{1-\beta}} \\
s & =1-\frac{\gamma}{q}\left[\frac{\delta+\rho}{\beta}(1-\eta)-\delta\right] \bar{K} \\
z & =\frac{(1-\mu)}{\gamma(1-\mu+r)}-\frac{(1+\gamma)(1-\mu)+\gamma r}{\gamma(1-\mu+r)}\left[1-\frac{\gamma}{q} R(1-\eta)\right]
\end{aligned}
$$

2. (OS):

$$
\begin{aligned}
M^{i} & =A^{i}\left(K-\bar{K}^{N}\right)^{\gamma} \\
N & =\left(\bar{K}^{N}\right)^{\beta} \\
Y & =\left(\bar{K}^{N}\right)^{\beta}+\phi p^{i} A^{i}\left(K-\bar{K}^{N}\right)^{\gamma} \\
\bar{K}^{N} & =\left(\frac{\beta}{\delta+\rho}\right)^{\frac{1}{1-\beta}} \\
p^{i} A^{i}\left(K-\bar{K}^{N}\right)^{\gamma} & =\frac{\rho+\delta}{\gamma \phi} \bar{K}^{N}\left[\frac{\frac{\rho+\delta}{\beta}(1-\eta)-\delta}{\frac{1-\phi}{\phi} \frac{\rho+\delta}{\gamma}+\delta}\right] \\
1+z & =\psi^{\frac{-1}{1-\mu}} \frac{\rho+\delta}{\gamma \phi} \frac{1}{p^{i}}\left(\bar{K}^{N}\right)^{1-\gamma}\left[\frac{\frac{\rho+\delta}{\beta}(1-\eta)-\delta}{\frac{1-\phi}{\phi} \frac{\rho+\delta}{\gamma}+\delta}\right]^{1-\gamma}
\end{aligned}
$$




\section{References}

[1] Allen, Beth (2002), "Design for Manufacturing," Unpublished Manuscript, University of Minnesota, Minneapolis, MN.

[2] Antras, Pol (2004), "Incomplete Contracts and the Product Cycle," American Economic Review (forthcoming).

[3] Bajari, Patrick and Steven Tadelis (2001), "Incentives versus transaction costs: a theory of procurement contracts," Rand Journal of Economics, 32, 387-407.

[4] Burdett, Kenneth and Dale T. Mortensen (1981), "Search, Layoffs, and Labor Market Equilibrium," Journal of Political Economy, 88, 652-672.

[5] Chen, Been-Lon and Koji Shimomura, 1998, Self-Fulfilling Expectations and Economic Growth: A Model of Technology Adoption and Industrialization, International Economic Review, 39, 151-170.

[6] Chen, Been-Lon, Jie-Ping Mo and Ping Wang (2002), "Technology Adoption, Growth and Matching," Journal of Economic Dynamics and Control, 26, 1927-1954.

[7] Ethier, Wilfred, "The Multinational Firm," The Quarterly Journal of Economics, 101, 805-834.

[8] Green, Jerry and Suzanne Scotchmer (1995) "On the Division of Profit between Sequential Innovators," The Rand Journal of Economics, 26, 20-33.

[9] O'Donaghue, Ted, Suzanne Scotchmer and Jacques Thisse (1998) "Patent Breadth, Patent Life, and the Pace of Technological Improvement," Journal of Economics and Management Strategy, 7, 1-32.

[10] Ghatak, Maitreesh and Priyanka Pandey (2000), "Contract Choice in Agriculture with Joint Moral Hazard in Effort and Risk," Journal of Development Economics, 63, 303-326.

[11] Grossman, Gene and Elhanan Helpman (2002), "Integration Versus Outsourcing in Industry Equilibrium," Quarterly Journal of Economics, 117, 85-120.

[12] Grossman, Gene and Elhanan Helpman (2004), "Outsourcing in a Global Economy," Review of Economic Studies (forthcoming).

[13] Grossman, Gene and Edwin L.-C. Lai (2004), "International Protection of Intellectual Property," American Economic Review (forthcoming). 
[14] Grossman, Sanford J. and Oliver D. Hart (1983), "An Analysis of the Principal-Agent Problem," Econometrica, 51, 7-45.

[15] Grossman, Sanford J. and Oliver D. Hart (1986), "The Costs and Benefits of Ownership: A Theory of Vertical and Lateral Integration," Journal of Political Economy, 94, 691-719.

[16] Harris, M. and A. Raviv (1979), Optimal Incentive Contracts with Imperfect Information," Journal of Economic Theory, 20, 231-259.

[17] Hart, Oliver D. and John Moore (1990), "Property Rights and the Nature of the Firm," Journal of Political Economy, 1119-1158.

[18] Horowitz, Andrew W. and Edwin L.-C. Lai (1996), "Patent Length and Rate of Innovation," International Economic Review, 37, 785-801.

[19] Jones, Ronald W. (2000), Globalization and the Theory of Input Trade, Cambridge MA: The MIT Press.

[20] Laing, Derek, Theodore Palivos and Ping Wang (1995), "Learning, Matching, and Growth," Review of Economic Studies, 62, 115-129.

[21] Milgrom, Paul (1988), "Employment Contract, Influence Activities and Efficient Organization Design," Journal of Political Economy, 96, 42-60.

[22] Milgrom, Paul and John Roberts (1992), Economics, Organization and Management, Englewood Cliffs, NJ: Prentice-Hall, chapter 6.

[23] Myerson, Roger B. (1983), "Mechanism Design by an Informed Principal," Econometrica, 51, 1767-1797.

[24] RËD Magazine, January 2001.

[25] Reinganum, Jennifer F. (1981), "Dynamic Games of Innovation," Journal of Economic Theory, 25, 21-41.

[26] Shell, Karl (1973), "Inventive Activity, Industrial Organisation and Economic Growth," in James A. Mirrlees and Nicolas Stern (edited), Models of Economic Growth, London, UK: Macmillan, 77-100.

[27] Spulber, Daniel 2007), "Innovation and International Trade in Technology," forthcoming Journal of Economic Theory. 


\section{CESifo Working Paper Series}

for full list see www.cesifo-group.org/wp

(address: Poschingerstr. 5, 81679 Munich, Germany, office@cesifo.de)

2156 Morris A. Davis and François Ortalo-Magné, Household Expenditures, Wages, Rents, December 2007

2157 Andreas Haufler and Christian Schulte, Merger Policy and Tax Competition, December 2007

2158 Marko Köthenbürger and Panu Poutvaara, Rent Taxation and its Intertemporal Welfare Effects in a Small Open Economy, December 2007

2159 Betsey Stevenson, Title IX and the Evolution of High School Sports, December 2007

2160 Stergios Skaperdas and Samarth Vaidya, Persuasion as a Contest, December 2007

2161 Morten Bennedsen and Christian Schultz, Arm's Length Provision of Public Services, December 2007

2162 Bas Jacobs, Optimal Redistributive Tax and Education Policies in General Equilibrium, December 2007

2163 Christian Jaag, Christian Keuschnigg and Mirela Keuschnigg, Pension Reform, Retirement and Life-Cycle Unemployment, December 2007

2164 Dieter M. Urban, Terms of Trade, Catch-up, and Home Market Effect: The Example of Japan, December 2007

2165 Marcelo Resende and Rodrigo M. Zeidan, Lionel Robbins: A Methodological Reappraisal, December 2007

2166 Samuel Bentolila, Juan J. Dolado and Juan F. Jimeno, Does Immigration Affect the Phillips Curve? Some Evidence for Spain, December 2007

2167 Rainald Borck, Federalism, Fertility and Growth, December 2007

2168 Erkki Koskela and Jan König, Strategic Outsourcing, Profit Sharing and Equilibrium Unemployment, December 2007

2169 Egil Matsen and Øystein Thøgersen, Habit Formation, Strategic Extremism and Debt Policy, December 2007

2170 Torben M. Andersen and Allan Sørensen, Product Market Integration and Income Taxation: Distortions and Gains from Trade, December 2007

2171 J. Atsu Amegashie, American Idol: Should it be a Singing Contest or a Popularity Contest?, December 2007 
2172 Patricia Apps and Ray Rees, Household Models: An Historical Perspective, December 2007

2173 Ben Greiner, Axel Ockenfels and Peter Werner, The Dynamic Interplay of Inequality and Trust - An Experimental Study, December 2007

2174 Michael Melvin and Magali Valero, The Dark Side of International Cross-Listing: Effects on Rival Firms at Home, December 2007

2175 Gebhard Flaig and Horst Rottmann, Labour Market Institutions and the Employment Intensity of Output Growth. An International Comparison, December 2007

2176 Alexander Chudik and M. Hashem Pesaran, Infinite Dimensional VARs and Factor Models, December 2007

2177 Christoph Moser and Axel Dreher, Do Markets Care about Central Bank Governor Changes? Evidence from Emerging Markets, December 2007

2178 Alessandra Sgobbi and Carlo Carraro, A Stochastic Multiple Players Multi-Issues Bargaining Model for the Piave River Basin, December 2007

2179 Christa Hainz, Creditor Passivity: The Effects of Bank Competition and Institutions on the Strategic Use of Bankruptcy Filings, December 2007

2180 Emilia Del Bono, Andrea Weber and Rudolf Winter-Ebmer, Clash of Career and Family: Fertility Decisions after Job Displacement, January 2008

2181 Harald Badinger and Peter Egger, Intra- and Inter-Industry Productivity Spillovers in OECD Manufacturing: A Spatial Econometric Perspective, January 2008

2182 María del Carmen Boado-Penas, Salvador Valdés-Prieto and Carlos Vidal-Meliá, the Actuarial Balance Sheet for Pay-As-You-Go Finance: Solvency Indicators for Spain and Sweden, January 2008

2183 Assar Lindbeck, Economic-Social Interaction in China, January 2008

2184 Pierre Dubois, Bruno Jullien and Thierry Magnac, Formal and Informal Risk Sharing in LDCs: Theory and Empirical Evidence, January 2008

2185 Roel M. W. J. Beetsma, Ward E. Romp and Siert J. Vos, Intergenerational Risk Sharing, Pensions and Endogenous Labor Supply in General Equilibrium, January 2008

2186 Lans Bovenberg and Coen Teulings, Rhineland Exit?, January 2008

2187 Wolfgang Leininger and Axel Ockenfels, The Penalty-Duel and Institutional Design: Is there a Neeskens-Effect?, January 2008

2188 Sándor Csengődi and Dieter M. Urban, Foreign Takeovers and Wage Dispersion in Hungary, January 2008 
2189 Joerg Baten and Andreas Böhm, Trends of Children's Height and Parental Unemployment: A Large-Scale Anthropometric Study on Eastern Germany, 1994 2006, January 2008

2190 Chris van Klaveren, Bernard van Praag and Henriette Maassen van den Brink, A Public Good Version of the Collective Household Model: An Empirical Approach with an Application to British Household Data, January 2008

2191 Harry Garretsen and Jolanda Peeters, FDI and the Relevance of Spatial Linkages: Do third Country Effects Matter for Dutch FDI?, January 2008

2192 Jan Bouckaert, Hans Degryse and Theon van Dijk, Price Discrimination Bans on Dominant Firms, January 2008

2193 M. Hashem Pesaran, L. Vanessa Smith and Takashi Yamagata, Panel Unit Root Tests in the Presence of a Multifactor Error Structure, January 2008

2194 Tomer Blumkin, Bradley J. Ruffle and Yosef Ganun, Are Income and Consumption Taxes ever really Equivalent? Evidence from a Real-Effort Experiment with Real Goods, January 2008

2195 Mika Widgrén, The Impact of Council's Internal Decision-Making Rules on the Future EU, January 2008

2196 Antonis Adam, Margarita Katsimi and Thomas Moutos, Inequality and the Import Demand Function, January 2008

2197 Helmut Seitz, Democratic Participation and the Size of Regions: An Empirical Study Using Data on German Counties, January 2008

2198 Theresa Fahrenberger and Hans Gersbach, Minority Voting and Long-term Decisions, January 2008

2199 Chiara Dalle Nogare and Roberto Ricciuti, Term Limits: Do they really Affect Fiscal Policy Choices?, January 2008

2200 Andreas Bühn and Friedrich Schneider, MIMIC Models, Cointegration and Error Correction: An Application to the French Shadow Economy, January 2008

2201 Seppo Kari, Hanna Karikallio and Jukka Pirttilä, Anticipating Tax Change: Evidence from the Finnish Corporate Income Tax Reform of 2005, January 2008

2202 Walter Krämer and André Güttler, On Comparing the Accuracy of Default Predictions in the Rating Industry, January 2008

2203 Syed M. Ahsan and Panagiotis Tsigaris, The Efficiency Loss of Capital Income Taxation under Imperfect Loss Offset Provisions, January 2008

2204 P. Mohnen, F. C. Palm, S. Schim van der Loeff and A. Tiwari, Financial Constraints and other Obstacles: Are they a Threat to Innovation Activity?, January 2008 
2205 Sascha O. Becker and Mathias Hoffmann, Equity Fund Ownership and the CrossRegional Diversification of Household Risk, January 2008

2206 Pedro R. D. Bom and Jenny E. Ligthart, How Productive is Public Capital? A MetaAnalysis, January 2008

2207 Martin Werding, Ageing and Productivity Growth: Are there Macro-level Cohort Effects of Human Capital?, January 2008

2208 Frederick van der Ploeg and Steven Poelhekke, Globalization and the Rise of MegaCities in the Developing World, February 2008

2209 Sara Biancini, Regulating National Firms in a Common Market, February 2008

2210 Jin Cao and Gerhard Illing, Liquidity Shortages and Monetary Policy, February 2008

2211 Mathias Kifmann, The Design of Pension Pay Out Options when the Health Status during Retirement is Uncertain, February 2008

2212 Laszlo Goerke, Tax Overpayments, Tax Evasion, and Book-Tax Differences, February 2008

2213 Jun-ichi Itaya and Heinrich W. Ursprung, Price and Death, February 2008

2214 Valentina Bosetti, Carlo Carraro and Emanuele Massetti, Banking Permits: Economic Efficiency and Distributional Effects, February 2008

2215 Assar Lindbeck, Mårten Palme and Mats Persson, Social Interaction and Sickness Absence, February 2008

2216 Gary E. Bolton and Axel Ockenfels, The Limits of Trust in Economic Transactions Investigations of Perfect Reputation Systems, February 2008

2217 Hartmut Egger and Peter Egger, The Trade and Welfare Effects of Mergers in Space, February 2008

2218 Dorothee Crayen and Joerg Baten, Global Trends in Numeracy 1820-1949 and its Implications for Long-Run Growth, February 2008

2219 Stephane Dees, M. Hashem Pesaran, L. Vanessa Smith and Ron P. Smith, Identification of New Keynesian Phillips Curves from a Global Perspective, February 2008

2220 Jerome L. Stein, A Tale of Two Debt Crises: A Stochastic Optimal Control Analysis, February 2008

2221 Michael Melvin, Lukas Menkhoff and Maik Schmeling, Automating Exchange Rate Target Zones: Intervention via an Electronic Limit Order Book, February 2008

2222 Raymond Riezman and Ping Wang, Preference Bias and Outsourcing to Market: A Steady-State Analysis, February 2008 